\title{
Charakterystyka i proweniencja piaskowców z gotyckiego portalu bazyliki św. Elżbiety Węgierskiej we Wroclawiu
}

\author{
Katarzyna Zboińska ${ }^{1,2}$, Wojciech Bartz ${ }^{1}$
}

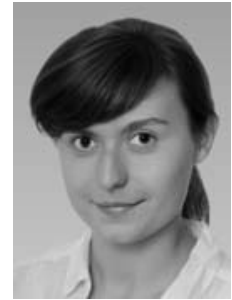

K. Zboińska

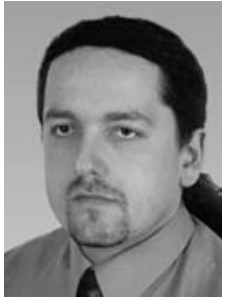

W. Bartz

Characterization and provenance of sandstones from the gothic portal of St. Elizabeth of Hungary basilica in Wroclaw. Prz. Geol., 67: 749-757; doi: 10.7306/2019.44

A b s tr a c t. The St. Elizabeth of Hungary Basilica is one of the most important and recognizable monuments of Wroclaw - the capital of Lower Silesia (SW part of Poland). The origin of the church dates back to the beginning of the $13^{\text {th }}$ century. The basilica received its present Gothic form in the $14^{\text {th }}-15^{\text {th }}$ centuries. At the foot of the church tower, overlooking the buildings of the nearby Market Square, there is a late-Gothic portal built in 1456. This is the oldest portal of the basilica. Adjacent to it, there are epitaphs of wealthy Wroctaw burghers. These monuments are the top-class works of Silesian stonemasonry and also an interesting example of the use of natural stone in constructing architectural details. From the portal and three epitaphs (devoted to the Krapps'family, Georg Althoff Scholz and Hans Schulz von Wolkovitz), a total of ten samples of clastic rock were collected. These were subjected to detailed petrographic and mineralogical studies in order to determine the provenance of the stone material. The research confirmed that these architectural details were made of quartz sandstones. The probable source of this material was the Cretaceous joint sandstones from the North-Sudetic Basin (Conacian, upper joint sandstone-Rakowice type).

Keywords: sandstones, petrography, provenance, Gothic portal, epitaphs

W ścisłym zabytkowym centrum Wrocławia, przy północno-wschodnim narożniku staromiejskiego Rynku, stoi kościół pw. św. Elżbiety (ryc. 1). Jest on uznawany za jeden z najcenniejszych zabytków miasta i stanowi wyraz potęgi średniowiecznych rodów mieszczańskich. W 2003 r. otrzymał miano bazyliki mniejszej, świadczące o wysokiej wartości zabytkowej i historycznej tego obiektu.

Wśród licznych portali zdobiących mury kościoła św. Elżbiety szczególną uwagę przykuwa bogato zdobiony, ostrołukowy portal u stóp monumentalnej wieży bazyliki, na jej południowej elewacji (ryc. 2). Jest to najstarszy z portali tej świątyni, gotycki, ukończony w 1456 r. (Antkowiak, 1991). Wraz z okalającymi go epitafiami stanowi interesujący przykład wykorzystania kamienia naturalnego w detalach architektonicznych i najwyższej klasy dzieło późnogotyckiej, śląskiej sztuki kamieniarskiej.

Interdyscyplinarne badania petroarcheologiczne, łączące elementy nauk o Ziemi z naukami historycznymi, przede wszystkim archeologią, a także zagadnienia zastosowania kamieni w architekturze zyskują ostatnio na popularności i doczekały się wielu opracowań naukowych (m.in. Skoczylas, 1991; Kryza, 2011; Prell, Zagożdżon, 2011; Bartz i in., 2015; Szczepaniak, 2015; Skoczylas, Gunia, 2016). Jednak o kościele św. Elżbiety we Wrocławiu wspominają nieliczni, m.in. Michniewicz (1996), Klementowski i Marcinów (2006) oraz Lorenc i Mazurek (2010).

Celem pracy jest próba określenia proweniencji materiału kamiennego użytego do wykonania późnogotyckiego portalu bazyliki św. Elżbiety Węgierskiej we Wrocławiu i trzech okalających go płyt epitafijnych: rodziny Krappów, Georga Althoffa Scholza oraz Hansa Schulza von Wolkovitz. Detale architektoniczne tego portalu i płyt, wyrzeźbione $\mathrm{z}$ podobnego makroskopowo piaskowca, pomimo wysokiej wartości zabytkowej nie zostały do tej pory pod-

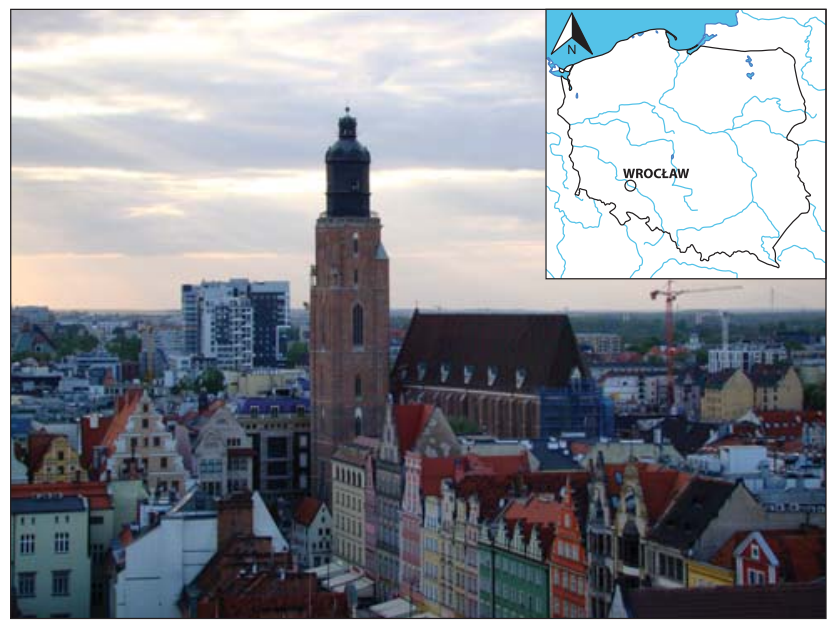

Ryc. 1. Kościół św. Elżbiety we Wrocławiu. Fot. M. Szadkowski Fig. 1. St. Elizabeth church in Wrocław. Photo by M. Szadkowski

dane szczegółowym badaniom. Dzięki prowadzonym pracom konserwatorskim udało się pozyskać próbki z portalu i towarzyszących mu epitafiów i opracować ich charakterystykę petrograficzno-mineralogiczną.

\section{HISTORIA BAZYLIKI ŚW. ELŻBIETY}

W 1978 r., podczas prac archeologicznych prowadzonych wokół kościoła św. Elżbiety Węgierskiej we Wrocławiu, odkryto pozostałości późnoromańskiej świątyni, zachowane w postaci kamiennej bazy budowli i fragmentów ceglanych murów (Antkowiak, 1991). Budowa tej świątyni jest datowana na pierwszą połowę XIII w. i wiązana z pierwszą lokacją miasta (Lasota, Piekalski, 1996). Ołtarz kościoła wykonano pierwotnie z granitu i cegieł. Podłoga

\footnotetext{
${ }^{1}$ Instytut Nauk Geologicznych, Uniwersytet Wrocławski, pl. Maksa Borna 9, 50-204 Wrocław; katarzyna.zboinska@uwr.edu.pl; wojciech.bartz@uwr.edu.pl

${ }^{2}$ Państwowy Instytut Geologiczny - Państwowy Instytut Badawczy, Oddział Dolnośląski, al. Jaworowa 19, 53-122 Wrocław
} 


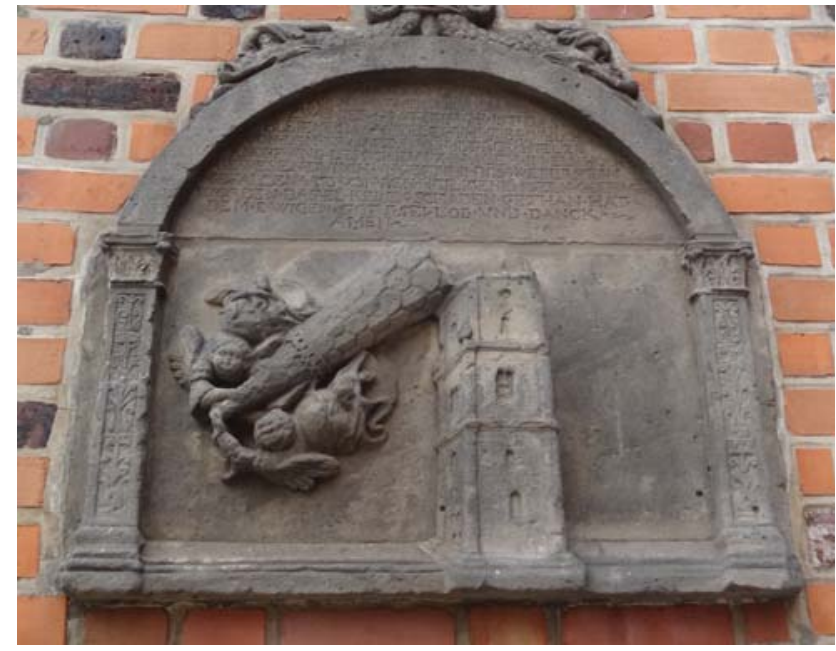

Ryc. 2. Płaskorzeźba przedstawiająca upadek gotyckiego hełmu wieży kościoła w 1529 r. Hełm podtrzymują w powietrzu aniołowie - zgodnie z legendą ich interwencja spowodowała, że podczas katastrofy nikt nie zginał (Antkowiak, 1991)

Fig. 2. Relief depicting the fall of the Gothic helmet of the church tower in 1529. The falling helmet is supported by angels - according to the legend, their intervention caused that during the catastrophe no one was killed (Antkowiak, 1991) początkowo była drewniana. Podczas kolejnych przebudów zastapiono ją posadzką wapienną, a później ceramiczną (Lasota, Piekalski, 1996).

Bazylikę w obecnej formie, gotyckiej, wznoszono od początków XIV w. do drugiej połowy XV w., kiedy ukończono budowę sklepienia, gotyckiego portalu oraz wieży kościoła. Ta monumentalna, trójnawowa budowla, mierzaca z zewnątrz 68,2 m długości i 34,4 m szerokości (Antkowiak, 1991), jest uznawana za jeden z najważniejszych zabytków Wrocławia i Dolnego Śląska.

Początkowo wieżę świątyni wieńczył strzelisty hełm, sięgający wysokości 130,48 m i dominujący nad ówczesnymi zabudowaniami miasta (Antkowiak, 1991). Jednak w 1529 r. runął on podczas wieczornej wichury na pobliskie budynki. Wydarzenie to zostało przedstawione na pamiątkowej płaskorzeźbie, zdobiącej elewację wieży (ryc. 2). Nowe zwieńczenie, renesansowe, powstało w latach 1533-1535 i było znacznie niższe - wraz z nim wieża liczy zaledwie 86,4 m (Maciejewska, 1997).

Upadek hełmu wieży był jedną z wielu katastrof, które dotknęły kościół św. Elżbiety w ciągu wieków jego istnienia. Bazylika była wielokrotnie uszkadzana podczas pożarów, wichur i działań wojennych. Nie wiadomo, czy i jakim uszkodzeniom ulegał gotycki portal i otaczające go dziś

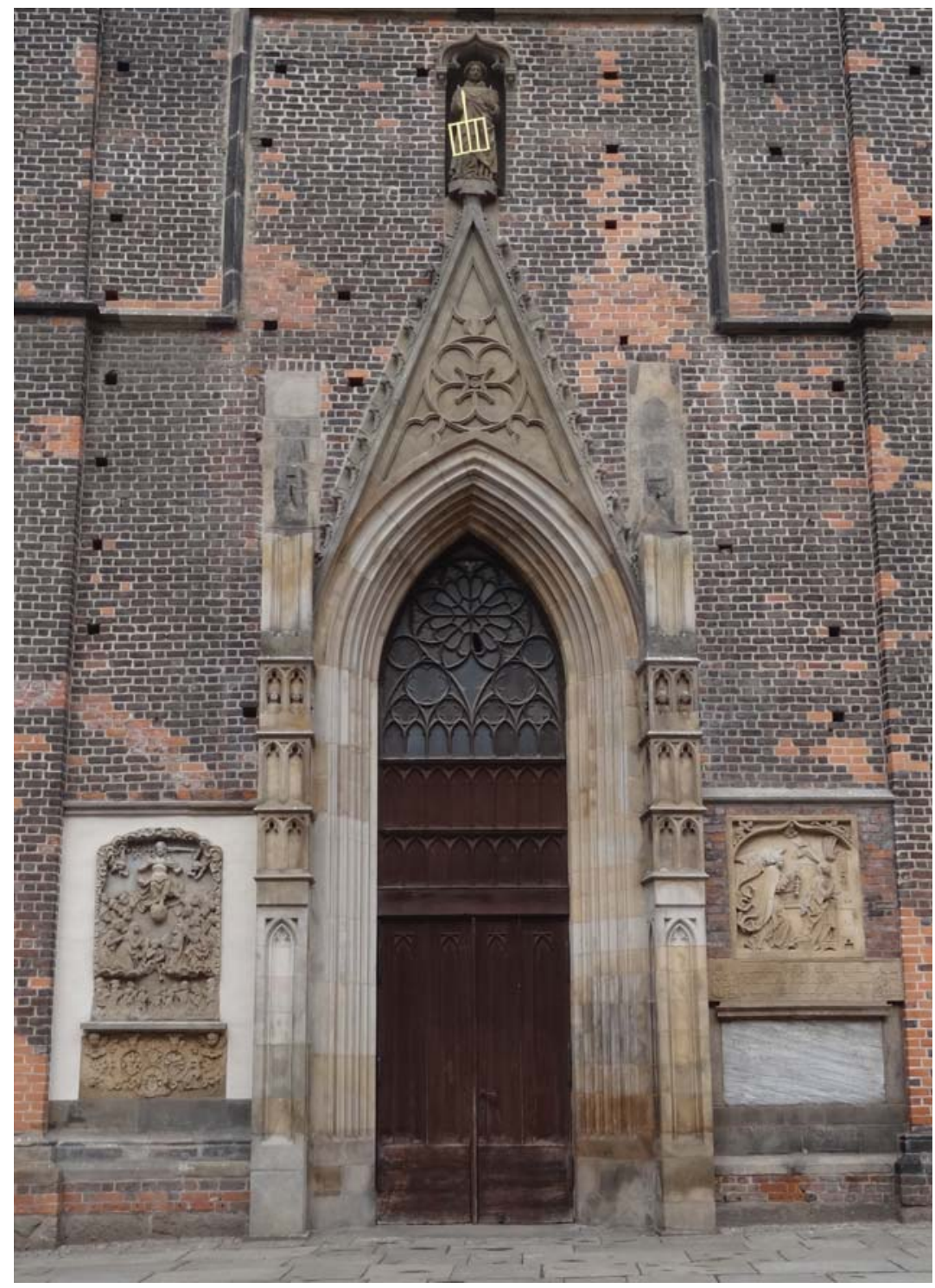

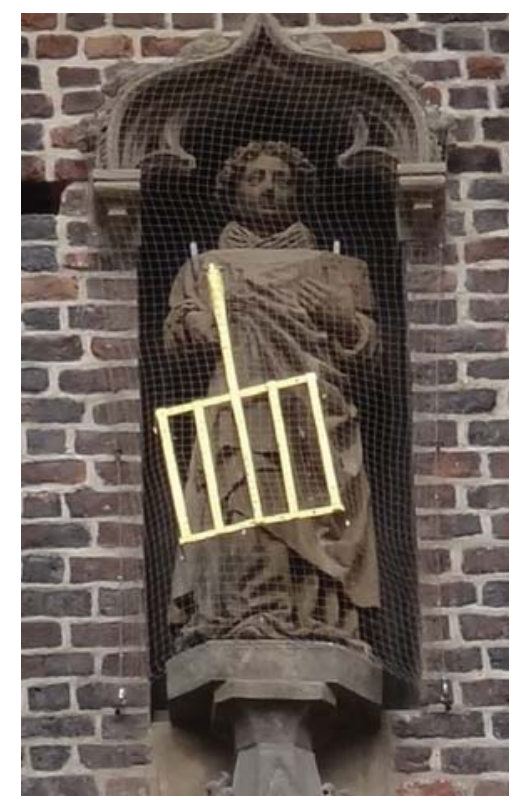

Ryc. 3. Gotycki portal wiodący do wieży kościoła św. Elżbiety we Wrocławiu wraz z otaczającymi go epitafiami. Wszystkie fot. K. Zboińska Fig. 3. Gothic portal at the foot of the tower of the St. Elizabeth church in Wrocław with adjacent epitaphs. All photos by K. Zboińska

Ryc. 4. Figura św. Wawrzyńca nad portalem kościoła św. Elżbiety we Wrocławiu

Fig. 4. Figure of St. Lawrence at the foot of the tower of the St. Elizabeth church in Wrocław 
płyty epitafijne, znane sa jednak informacje o historycznych przebudowach portalu i zabiegach konserwatorskich (Wandrychowska, 2013a).

\section{ARCHITEKTURA GOTYCKIEGO PORTALU}

Najstarszy, gotycki portal kościoła św. Elżbiety wieńczy wimperga (ryc. 3) - dekoracyjne wykończenie o trójkątnym kształcie, z rzeźbionym ślepym maswerkiem, tj. geometrycznym wzorem w polu trójkąta. Krawędzie wimpergi okalają ozdobne detale, zwane czołgankami (Wandrychowska, 2013a). Na szczycie wimpergi znajduje się figura św. Wawrzyńca - patrona wieży, który trzyma w ręce ruszt - atrybut swojej męczeńskiej śmierci (ryc. 4). Po obu stronach wejścia są ulokowane fiale - strzeliste, smukłe, czworoboczne wieżyczki, dekorowane częściowo otworami. Ozdobne zagłębienia są wykończone trójlistnymi zwieńczeniami i tworzą trzy poziomy, z których najwyższy mieści w

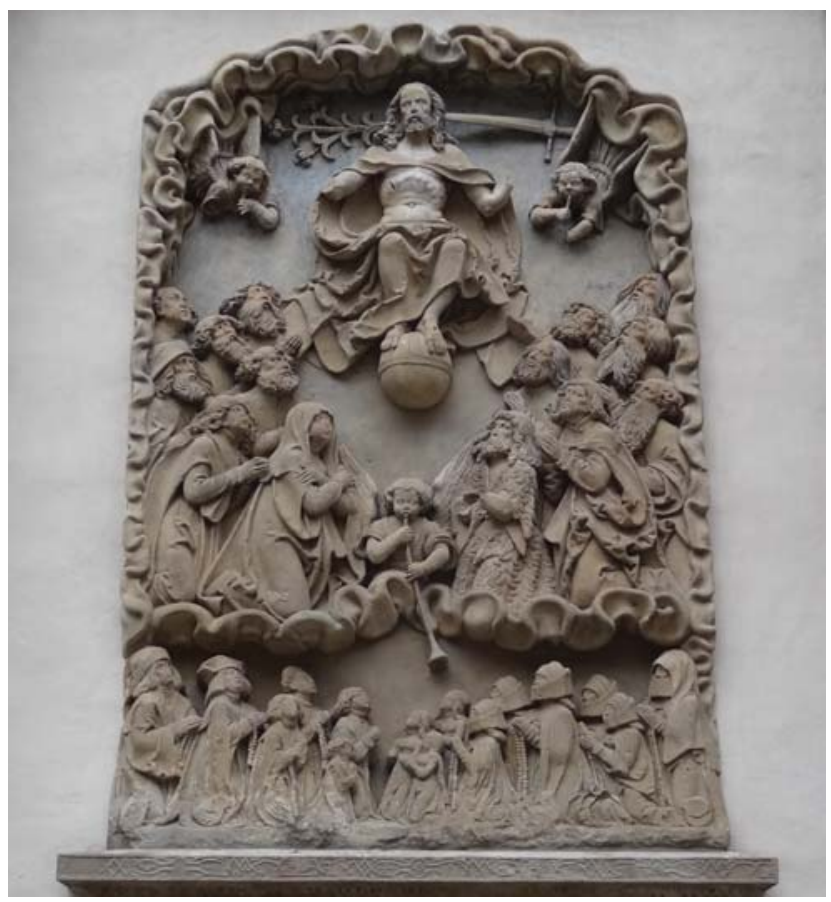

Ryc. 5. Epitafium rodziny Krappów Fig. 5. The Krapps' family epitaph

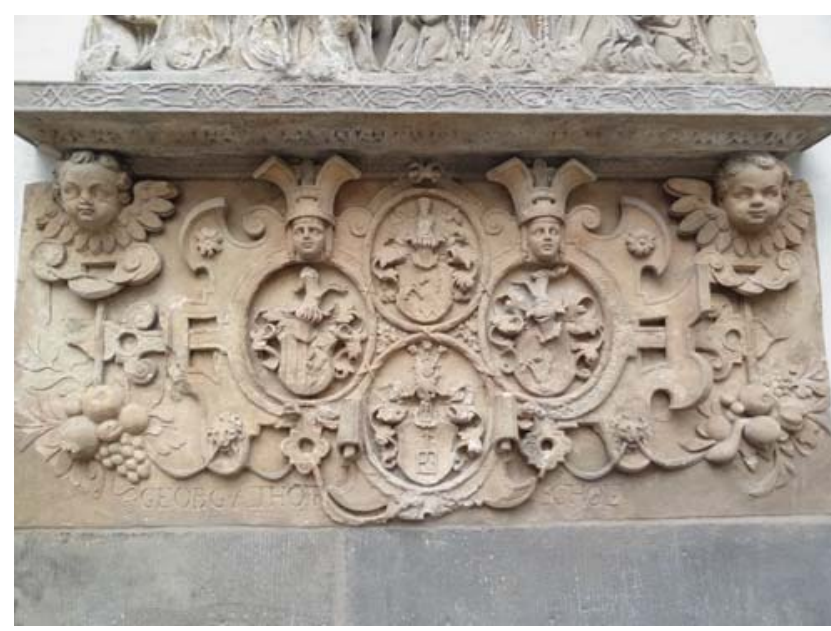

Ryc. 6. Epitafium Georga Althoffa Scholza

Fig. 6. Georg Althoff Scholz's epitaph

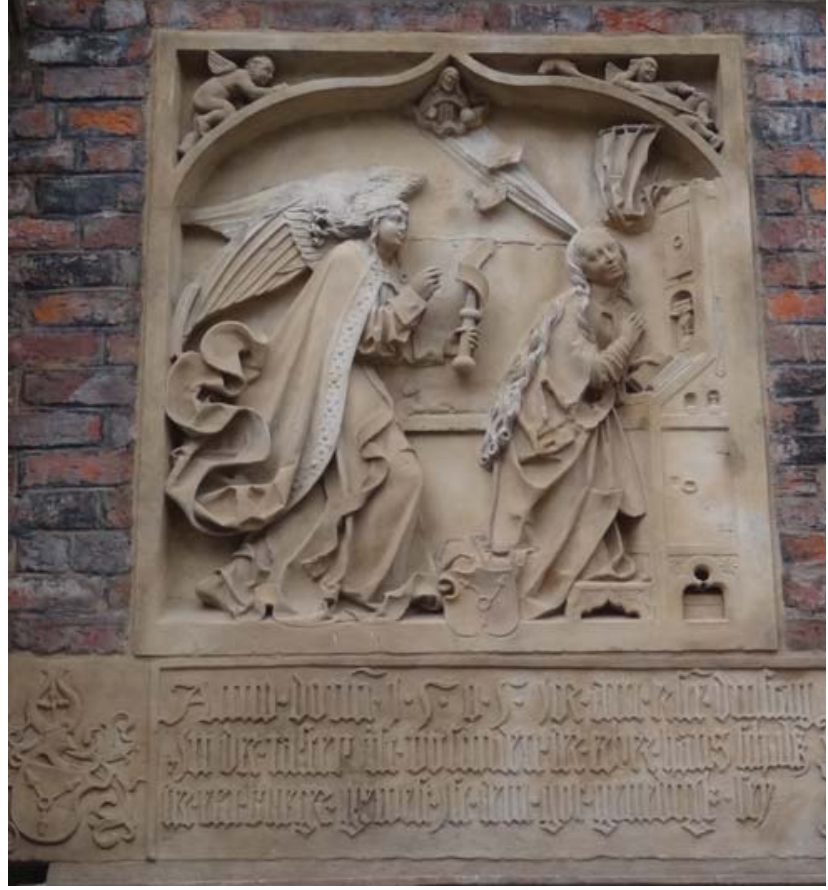

Ryc. 7. Epitafium Hansa Schulza von Wolkovitz

Fig. 7. Hans Schulz von Wolkovitz's epitaph

otworach kamienne popiersia kobiet i mężczyzn w strojach świeckich (Wandrychowska, 2013a).

Ściany po obu stronach portalu zdobią epitafia. Po lewej stronie znajduje się dekoracyjna płaskorzeźba z $1497 \mathrm{r}$., poświęcona rodzinie Krappów, majętnych wrocławskich mieszczan. Przedstawia ona scenę Sądu Ostatecznego (ryc. 5). Pierwotnie epitafium to było pokryte polichromią i znajdowało się w przylegającej do wieży kaplicy Krappów, rozebranej w XIX w. (Wandrychowska, 2013b). Poniżej znajduje się epitafium Georga Althoffa Scholza z 1604 r. (ryc. 6) w formie prostokątnej płyty ze znakami herbowymi. Tę dekoracyjną płytę heraldyczno-ornamentalną wykonano w stylu renesansowym i umieszczono na niej cztery owalne pola z herbami. W górnych narożach epitafium są głowy aniołków (putta), w dolnych wyrzeźbiono owoce (Wandrychowska, 2013c). Po prawej stronie portalu znajduje się późnogotyckie epitafium Hansa Schultza von Wolkovitza (ryc. 7), wykonane po 1505 r., składające się z dwóch płyt: górnej, przedstawiającej scenę zwiastowania Najświętszej Maryi Pannie oraz dolnej tablicy inskrypcyjnej z dwoma znakami herbowymi (Wandrychowska, 2013d). Poniżej została wbudowana marmurowa płyta inskrypcyjna, poświęcona pamięci Ehrenfrieda Fellnera i jego żony, Anny Reginy (Wandrychowska, 2013e).

\section{MATERIAŁY I METODY BADAŃ}

Z późnogotyckiego portalu i przyległych do niego trzech płyt epitafijnych pobrano do analiz 10 próbek piaskowców (ryc. 8). Ze względu na zabytkowe znaczenie badanego obiektu wszystkie próbki cechowały się niewielkimi rozmiarami (rzędu 2-3 cm). Wybór metod badawczych, którym poddano próbki (tab. 1), został podyktowany przede wszystkim niewielką ilością materiału skalnego pozyskanego do badań oraz chęcią otrzymania możliwie największej liczby danych. 
W celu wstępnego scharakteryzowania składu mineralogicznego skał użytych do wykonania portalu i epitafiów z materiału pobranego do badań wykonano preparaty mikroskopowe i obserwowano je w świetle przechodzącym (PM) pod mikroskopem polaryzacyjnym firmy Zeiss. Wykonano także mikrofotografie tych skał i poddano je komputerowej analizie obrazu (CIA) z wykorzystaniem oprogramowania JMicroVision (Roduit, 2007), podczas której zmierzono wielkość ziaren mineralnych (największą średnicę zastępczą przekroju). Na podstawie wyników tych pomiarów obliczono i opisano geometryczne i statystyczne parametry uziarnienia, a także określono skład modalny próbek.

Skład mineralny spoiwa 5 próbek z portalu i epitafiów (tab. 1) określono na podstawie skaningowej kalorymetrii różnicowej i termograwimetrii (DSC-TG) przy użyciu kalorymetru Perkin Elmer STA 6000 (tab. 1). Badany materiał delikatnie zdezintegrowano w moździerzu agatowym, a przypisaną do spoiwa frakcję poniżej $63 \mu \mathrm{m}$ odsiano na sicie. Próbki o masie naważek od ok. 36 do $87 \mathrm{mg}$ (w zależności od dostępnego materiału) analizowano w temperaturze $40-999^{\circ} \mathrm{C}$, zadając prędkość podgrzewania $15^{\circ} \mathrm{C} / \mathrm{min}$.

Dwie próbki (P5 i P6 - tab. 1) poddano badaniom proszkowej dyfrakcji rentgenowskiej (PXRD) na dyfraktometrze BRUKER D5000, wyposażonym w lampę $\mathrm{z}$ anodą kobaltową, która pracowała w warunkach natężenia prądu do $30 \mathrm{~mA}$ i pod napięciem $40 \mathrm{kV}$. Zakres pomiarów wynosił od 5 do $75^{\circ}$ przy postępie 2 Theta $=0,02^{\circ} / \mathrm{s}$. Interpretacji

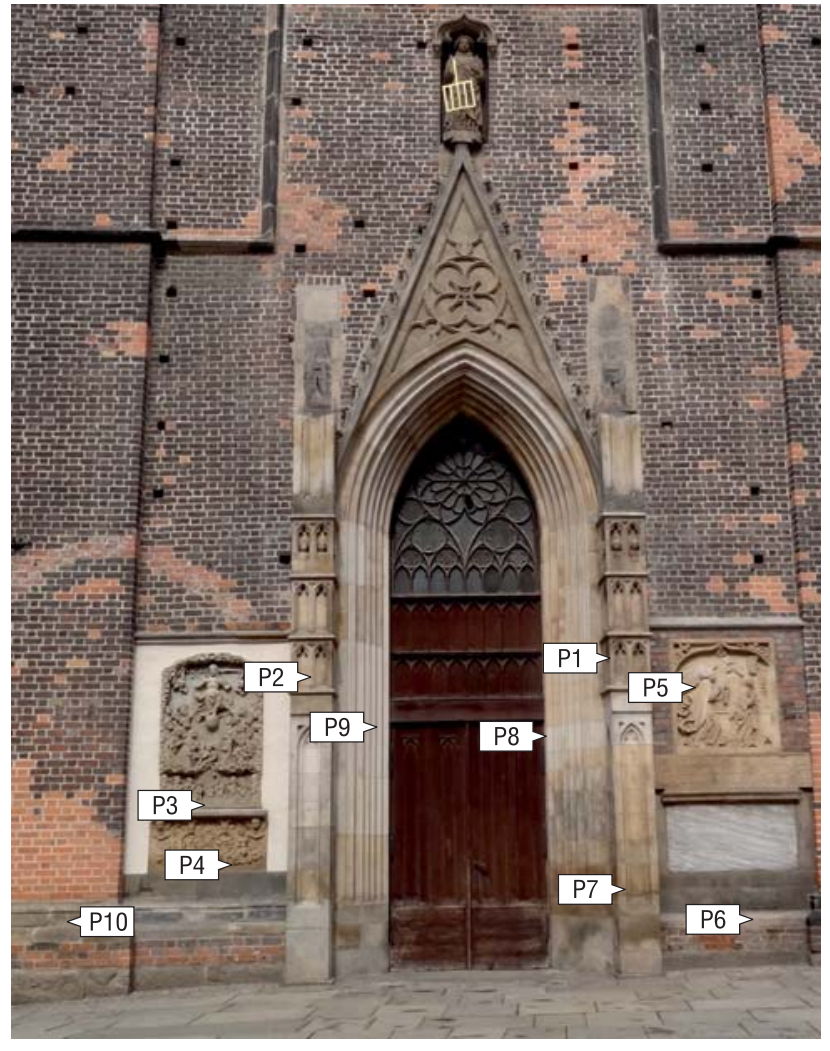

Ryc. 8. Miejsca pobrania próbek skał z portalu i epitafiów

Fig. 8. Places of rock sampling from the portal and epitaphs

Tab. 1. Zestawienie badań, jakim poddano próbki skał okruchowych z gotyckiego portalu kościoła św. Elżbiety we Wrocławiu i trzech towarzyszących mu epitafiów

Table 1. List of samples of clastic rocks taken from the Gothic portal and three adjacent epitaphs from the St. Elizabeth church in Wrocław with information about the conducted analyzes

\begin{tabular}{|c|c|c|c|c|c|c|c|}
\hline $\begin{array}{l}\text { Nazwa próbki } \\
\text { Sample name }\end{array}$ & $\begin{array}{l}\text { Miejsce pobrania próbki } \\
\text { Place of sampling }\end{array}$ & $\mathbf{P M}$ & CIA & DSC-TG & XRD & SEM-EDS & CL \\
\hline P1 & $\begin{array}{l}\text { Pinakiel od strony wschodniej, } \\
\text { I poziom dekoracyjnych zagłębien } \\
\text { Pinnacle from the E side, } \\
I^{\text {st }} \text { level of decorative hole }\end{array}$ & + & + & & & & \\
\hline $\mathrm{P} 2$ & $\begin{array}{l}\text { Pinakiel od strony zachodniej, } \\
\text { I poziom dekoracyjnych zagłębień } \\
\text { Pinnacle from the } W \text { side, } I^{\text {st }} \text { level of decorative hole }\end{array}$ & + & + & + & & + & + \\
\hline P3 & $\begin{array}{l}\text { Epitafium rodziny Krappów, czesść dolna } \\
\text { The Krapps' family epitaph, the lower part }\end{array}$ & + & + & & & & \\
\hline P4 & $\begin{array}{l}\text { Epitafium Georga Althoffa Scholza, częśc dolna } \\
\text { The Georg Althoff Scholz's epitaph, the lower part }\end{array}$ & + & + & + & & & \\
\hline P5 & $\begin{array}{l}\text { Epitafium Hansa Schulza von Wolkovitz, } \\
\text { skrzydło archanioła Gabriela } \\
\text { The Hans Schulz von Wolkovitz’s epitaph, } \\
\text { wing of the archangel Gabriel }\end{array}$ & + & + & + & + & & + \\
\hline P6 & $\begin{array}{l}\text { Styk bloków ponad gzymsem, poniżej marmurowego } \\
\text { epitafium Ehrenfrieda Fellnera i jego żony, Anny Reginy } \\
\text { The contact of the blocks above the cornice, below the marble } \\
\text { epitaph of Ehrenfried Fellner and his wife, Anna Regina }\end{array}$ & + & + & & & & \\
\hline P7 & $\begin{array}{l}\text { Pinakiel od strony wschodniej, dolna część } \\
\text { Pinnacle from the E side, the lower part }\end{array}$ & + & + & + & + & + & \\
\hline P8 & $\begin{array}{l}\text { Ościeże od strony wschodniej } \\
\text { Jamb from the E side }\end{array}$ & + & + & & & + & \\
\hline P9 & $\begin{array}{l}\text { Ościeże od strony zachodniej } \\
\text { Jamb from the } W \text { side }\end{array}$ & + & + & & & & \\
\hline P10 & $\begin{array}{l}\text { Styk bloków kamiennych pod gzymsem } \\
\text { Contact of stone blocks under the cornice }\end{array}$ & + & + & + & & & + \\
\hline
\end{tabular}

PM - obserwacje pod mikroskopem plaryzacyjnym / observation under the polarizing microscope; CIA - komputerowa analiza obrazu /

computer image analysis; DSC-TG - skaningowa kalorymetria różnicowa / differential scanning calorimetry; XRD - dyfrakcja promieniowania rentgenowskiego / X-ray diffraction; SEM-EDS - scanningowa mikroskopia elektronowa - elektrony wstecznie rozproszone / scanning electron microscopy - back scattered electrons); $\mathbf{C L}$ - katodoluminescencja / cathodoluminescense 
uzyskanych dyfraktogramów dokonano z użyciem oprogramowania X'Pert High Score Plus.

Trzy próbki (P2, P6 i P7 - tab. 1, ryc. 8) napylono węglem i analizowano z użyciem skaningowego mikroskopu elektronowego Jeol JSM IT-100, wyposażonego w przystawkę Oxford EDS (SEM-EDS). Badanie to umożliwiło przeprowadzenie obserwacji form mineralnych i szczegółowe określenie składu fazowego.

Ostatnią z zastosowanych metod była mikroskopia katodoluminescencyjna (CL). Wykorzystano ją do zbadania próbek P2, P5 i P10 (tab. 1, ryc. 8) z użyciem zimnej katody Cambridge Image Technology Ltd. CL mk3a.

Spoiwo piaskowców z portalu i epitafiów (tab. 1) poddano skaningowej kalorymetrii różnicowej i termograwimetrii (DSC-TG) oraz proszkowej dyfrakcji rentgenowskiej (XRD), a także obserwacjom w skaningowym mikroskopie elektronowym z przystawką EDS (SEM-EDS) oraz bada- niom katodoluminescencyjnym (CL). Uzyskane obrazy katodoluminescencyjne porównano $\mathrm{z}$ wynikami badań piaskowców Dolnego Sląska, opublikowanymi przez Ehling (1999) i Szczepaniak (2015).

$\mathrm{Na}$ podstawie danych literaturowych (Kamieński, Kubicz, 1962; Ehling, 1999; Labus, 2011; Szczepaniak, 2015) jako potencjalne źródło materiału skalnego do budowy bazyliki św. Elżbiety wytypowano złoża ciosowych piaskowców kredowych z niecki północnosudeckiej i niecki śródsudeckiej, które były wykorzystywane do celów budowlanych w czasach historycznych. Z trzech wybranych wychodni piaskowców - typu Lwówek Śląski (cenoman), Płakowice (turon) i Rakowice (koniak) - pobrano do badań referencyjne próbki skał. Wyniki analiz mikroskopowych oraz komputerowej analizy obrazu (PM, CIA, DSC-TG, PXRD, SEM-EDS) umożliwiły porównanie mineralnego składu próbek zabytkowych i referencyjnych (tab. 2).

Tab. 2. Skład mineralny szkieletu ziarnowego i spoiwa w badanych próbkach zabytkowych i próbkach piaskowców referencyjnych Tab. 2. Mineral composition of the grain skeleton and cement in the examined historical samples and reference sandstone samples

\begin{tabular}{|c|c|c|c|c|c|c|c|c|c|c|}
\hline & \multicolumn{7}{|c|}{ Szkielet ziarnowy / Grain skeleton } & \multicolumn{3}{|c|}{ Spoiwo / Cement } \\
\hline & 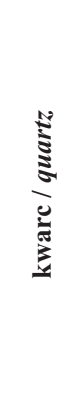 & 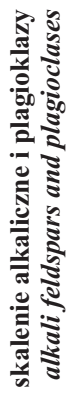 & 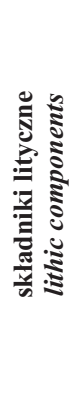 & 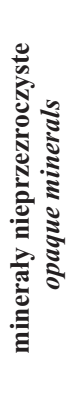 & 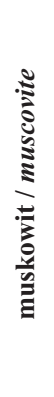 & 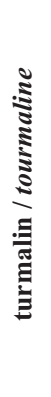 & 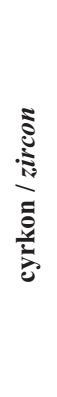 & 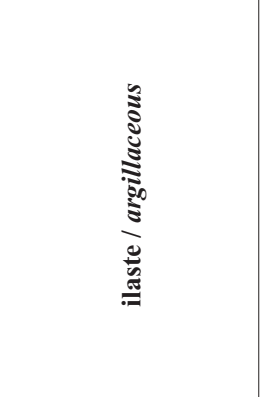 & 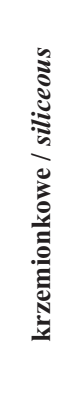 & 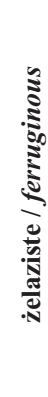 \\
\hline \multicolumn{11}{|c|}{ Próbki zabytkowe / Historical samples } \\
\hline P1 & +++ & + & + & - & - & - & - & $++*$ & +++ & + \\
\hline P2 & +++ & + & + & - & - & - & - & $\begin{array}{c}++(\text { kaolinit/kaolinite }) \\
+(\text { (illit/illite })\end{array}$ & +++ & ++ \\
\hline P3 & +++ & + & - & + & - & + & - & $++*$ & +++ & + \\
\hline P4 & +++ & + & - & + & + & - & - & $\begin{array}{l}+ \text { +(kaolinit/kaolinite }) \\
+(\text { illit/illite })\end{array}$ & +++ & + \\
\hline P5 & +++ & + & - & + & + & + & + & ++ (kaolinit/kaolinite $)$ & +++ & + \\
\hline P6 & +++ & + & + & + & - & + & - & $++*$ & +++ & + \\
\hline $\mathrm{P} 7$ & +++ & + & + & + & - & - & - & $\begin{array}{l}+ \text { +(kaolinit/kaolinite }) \\
+(\text { illit/illite })\end{array}$ & +++ & + \\
\hline P8 & +++ & + & - & - & + & + & - & $\begin{array}{l}+ \text { (kaolinit/kaolinite }) \\
+(\text { illit/illite })\end{array}$ & +++ & + \\
\hline P9 & +++ & + & + & + & + & + & + & $++*$ & +++ & ++ \\
\hline P10 & +++ & + & + & + & + & + & + & $\begin{array}{l}++ \text { (kaolinit/kaolinite }) \\
+(\text { illit/illite })\end{array}$ & +++ & + \\
\hline \multicolumn{11}{|c|}{ Piaskowce referencyjne / Reference sandstone samples } \\
\hline $\begin{array}{l}\text { typu / type Lwówek Śląski } \\
\text { (cenoman / Cenomanian) }\end{array}$ & +++ & + & + & + & + & + & + & $\begin{array}{l}++(\text { kaolinit/kaolinite }) \\
+(\text { illit/illite })\end{array}$ & +++ & ++ \\
\hline $\begin{array}{l}\text { typu / type Płakowice } \\
\text { (turon / Turonian) }\end{array}$ & +++ & + & + & + & + & + & + & ++ (kaolinit/kaolinite) & +++ & + \\
\hline $\begin{array}{l}\text { typu / type Rakowice } \\
\text { (koniak / Coniacian) }\end{array}$ & +++ & + & + & + & + & + & + & $\begin{array}{l}++(\text { kaolinit/kaolinite }) \\
+(\text { illit } / \text { illite })\end{array}$ & +++ & + \\
\hline
\end{tabular}

+++ znacząca zawartość składnika / abundant component; ++ składnik podrzędny / sub-component;

+ niewielka zawartość składnika / low content of component;

- składnika nie stwierdzono / component not found;
* nie analizowano szczegółowo ze względu na niedostateczną ilość materiału badawczego

* not analyzed in detail due to the insufficient amount of research material 


\section{WYNIKI BADAŃ}

Próbki pobrane z gotyckiego portalu kościoła św. Elżbiety oraz trzech okalających go płyt epitafijnych reprezentują skały okruchowe frakcji piaskowej. Makroskopowo różnią się one barwą która zmienia się od bladożółtej po szarobrązową. $\mathrm{Na}$ podstawie obserwacji mikroskopowych można stwierdzić, że w składzie ich szkieletu ziarnowego dominuje kwarc, stanowiący w poszczególnych próbkach od ok. 95 do $98 \%$ obj. szkieletu ziarnowego (ryc. 9). Zawartość innych ziaren, takich jak fragmenty lityczne czy składniki akcesoryczne, $\mathrm{t} j$. minerały nieprzezroczyste, turmalin, muskowit i cyrkon, jest nieznaczna i nie pojawiaja się one we wszystkich próbkach (tab. 2). W związku z tym można uznać, że do wykonania badanych detali architektonicznych użyto piaskowców kwarcowych.

Wielkość ziaren mineralnych jest w niewielkim stopniu zróżnicowana. W 7 z 10 zabytkowych próbek skał dominuje przedział uziarnienia $0,25-0,50 \mathrm{~mm}$ (tab. 3 ; ryc. 9), toteż należy je zaliczyć do piaskowców średnioziarnistych. Pozostałe 3 próbki cechują się dominacją drobniejszego ziarna $\mathrm{i}$ przedziałem modalnym ziaren $\mathrm{w}$ zakresie 0,125-0,25 mm (tab. 3). Zatem można je sklasyfikować jako piaskowce drobnoziarniste. Stopień obtoczenia ziaren we wszystkich próbkach jest średni do dobrego, przeważnie są one półostrokrawędziste, półobtoczone i obtoczone.

Tab. 3. Geometryczne i statystyczne parametry uziarnienia próbek skał okruchowych z późnogotyckiego portalu kościoła św. Elżbiety we Wrocławiu i trzech towarzyszących mu epitafiów

Table 3. Geometrical and statistical parameters for clastic rocks samples from the late Gothic portal from the St. Elizabeth church in Wrocław and three epitaphs

\begin{tabular}{|l|c|c|c|c|}
\hline \multirow{2}{*}{$\begin{array}{c}\text { Nazwa } \\
\text { próbki } \\
\begin{array}{c}\text { Sample } \\
\text { name }\end{array}\end{array}$} & $\mathbf{M}_{\mathbf{d}}$ & $\mathbf{P M}$ & $\mathbf{Q}_{\mathbf{1}}$ & $\mathbf{Q}_{\mathbf{3}}$ \\
\cline { 2 - 5 } & Parametr / Parameter $[\mathbf{m m}]$ \\
\hline P1 & 0,33 & $0,25-0,50$ & 0,19 & 0,44 \\
\hline P2 & 0,32 & $0,25-0,50$ & 0,19 & 0,43 \\
\hline P4 & 0,27 & $0,25-0,50$ & 0,19 & 0,36 \\
\hline P5 & 0,13 & $0,125-0,25$ & 0,07 & 0,19 \\
\hline P6 & 0,18 & $0,125-0,25$ & 0,09 & 0,25 \\
\hline P7 & 0,25 & $0,25-0,50$ & 0,1 & 0,38 \\
\hline P8 & 0,28 & $0,25-0,50$ & 0,11 & 0,4 \\
\hline P9 & 0,21 & $0,25-0,50$ & 0,12 & 0,29 \\
\hline P10 & 0,18 & $0,125-0,25$ & 0,08 & 0,26 \\
\hline
\end{tabular}

$\mathbf{M}_{\mathrm{d}}$ - mediana uziarnienia - połowa ziaren jest mniejsza od mediany, a połowa większa (Folk, 1980) / median; the value in the middle of the set - half of the grain is smaller than the median, and half is larger (Folk, 1980)

PM - przedział modalny; największy (najbardziej liczny) przedział wielkości ziaren, determinujący nazwę skał okruchowych / modal interval; the largest (most numerous) grain size range, determining the name of the clastic rocks

$\mathbf{Q}_{1}$ - I kwartyl; wartość, poniżej której znajduje się 25\% przeprowadzonych obserwacji (pomiarów), a $75 \%$ powyżej / I quartile; the value below which there is $25 \%$ of observations (measurements), and $75 \%$ is above

$\mathbf{Q}_{3}$ - III kwartyl; wartość, poniżej której znajduje się $75 \%$ przeprowadzonych obserwacji (pomiarów), a $25 \%$ powyżej / III quartile; the value below which there is $75 \%$ of observations (measurements), and $25 \%$ is above
Badane skały różnią się pod względem zawartości detrytycznego matriksu (reprezentowanego przez frakcję mniejszą od $0,063 \mathrm{~mm}$ ), stanowiącego w całej populacji ziaren, w zależności od próbki, od $4 \%$ do $24 \%$. Matrix tworzą bardzo drobne ziarna i mimo dużej liczebności objętościowo stanowią one poniżej $15 \%$ skały, co pozwala na zakwalifikowanie analizowanych piaskowców do arenitów kwarcowych (Pettijohn i in., 1987). Spoiwo tych skał jest krzemionkowo-ilaste, $\mathrm{z}$ domieszkami związków żelaza (tab. 2).

$\mathrm{Na}$ termogramach uzyskanych metodą DSC-TG (tj. krzywych termicznych i wagowych) powszechnie ujawniły się efekty wskazujące na obecność w spoiwie minerałów ilastych (Földvári, 2011), takich jak kaolinit, rzadziej illit (tab. 2). Także wyniki analizy XRD potwierdziły obecność minerałów ilastych $\mathrm{w}$ spoiwie, $\mathrm{w}$ tym refleksy o niewielkiej względnej intensywności, które zinterpretowano jako pochodzace od kaolinitu $(\mathrm{d}=7,18 \AA)$. Obserwacje SEM-EDS ujawniły, że minerały ilaste występują najczęściej w postaci ,robakowatych” pakietów, charakterystycznych dla kaolinitu, tworzonych przez połączone ze sobą drobne blaszki (ryc. 5), a rzadziej w formie groniastej i zbitej (typowej dla illitu), obrastającej ziarna kwarcu i wypełniającej przestrzenie pomiędzy ziarnami szkieletu.

Na podstawie wyników badań DSC-TG w spoiwie badanych próbek stwierdzono kwarc, obserwowany już pod mikroskopem polaryzacyjnym, oraz hydroksytlenki żelaza: getyt $\alpha-\mathrm{FeOOH}$ i lepidokrokit $\gamma-\mathrm{FeOOH}$.

Rezultaty analizy termicznej wskazują na obecność w spoiwie piaskowców z portalu i epitafiów składników mniej typowych, takich jak gips i węglany (kalcyt). Obecność gipsu potwierdzają dodatkowo wyniki badań XRD (refleks d = 7,63 $\AA$ ) oraz SEM-EDS, gdzie gips jest miejscami dostrzegalny w postaci niedużych, krzyżujących się tabliczek, zarastających przestrzenie międzyziarnowe. Uznać należy, że minerały ilaste i hydroksytlenki żelaza stanowią pierwotny skład spoiwa, kwarc jest elementem, który pozostał w próbkach mimo odsiewania na sicie, natomiast węglany (kalcyt) i gips są substancjami wtórnymi.

Reakcja dehydratacji gipsu jest wyraźnie dostrzegalna $\mathrm{w}$ analizie termicznej. Zazwyczaj ma ona przebieg 2-etapowy - najpierw gips $\mathrm{CaSO}_{4} \cdot 2 \mathrm{H}_{2} \mathrm{O}$, oddając $1,5 \mathrm{H}_{2} \mathrm{O}$, przechodzi w półwodzian $\beta-\mathrm{CaSO}_{4} \cdot 0,5 \mathrm{H}_{2} \mathrm{O}$, a następnie woda jest całkowicie usuwana $\mathrm{z}$ jego struktury i powstaje $\gamma-\mathrm{CaSO}_{4}$ (Földvári, 2011; Ramachandran i in., 2002).

Węglany bardzo łatwo ulegają mobilizacji, przez co mogą być rozpuszczane przez wody opadowe i odkładane w skałach przed wydobyciem ich ze złoża i wykorzystaniem do celów budowlanych (Michniewicz, 1996). Ich migrację może też powodować podsiąkanie wód gruntowych lub filtracja wód opadowych (Michniewicz, 1996). Węglany stwierdzone w badanych próbkach piaskowców mogły pochodzić z sąsiednich elementów architektonicznych - z zapraw wapiennych i detali wykonanych ze skał wapiennych (np. pobliskiej węglanowej płyty epitafijnej).

Obecność gipsu można wyjaśnić tym, że badane próbki skał pochodzą $\mathrm{z}$ elewacji budynku usytuowanego $\mathrm{w}$ centrum dużego miasta, w którego atmosferze znajdują się związki siarki pochodzące ze spalania paliw kopalnych (przede wszystkim $\mathrm{SO}_{2}$ ). Związki te mogą wpływać na tempo wietrzenia skał, a w połączeniu z węglanami prowadzić do powstania gipsu (Michniewicz, 1996). Jednocześnie Michniewicz (1996) zauważa, że katalizatorem reakcji $\mathrm{SO}_{2} \mathrm{z}$ jonami węglanowymi mogą być takie pierwiastki, jak Fe i Mn, a jak już wspomniano, hydroksytlenki żelaza 

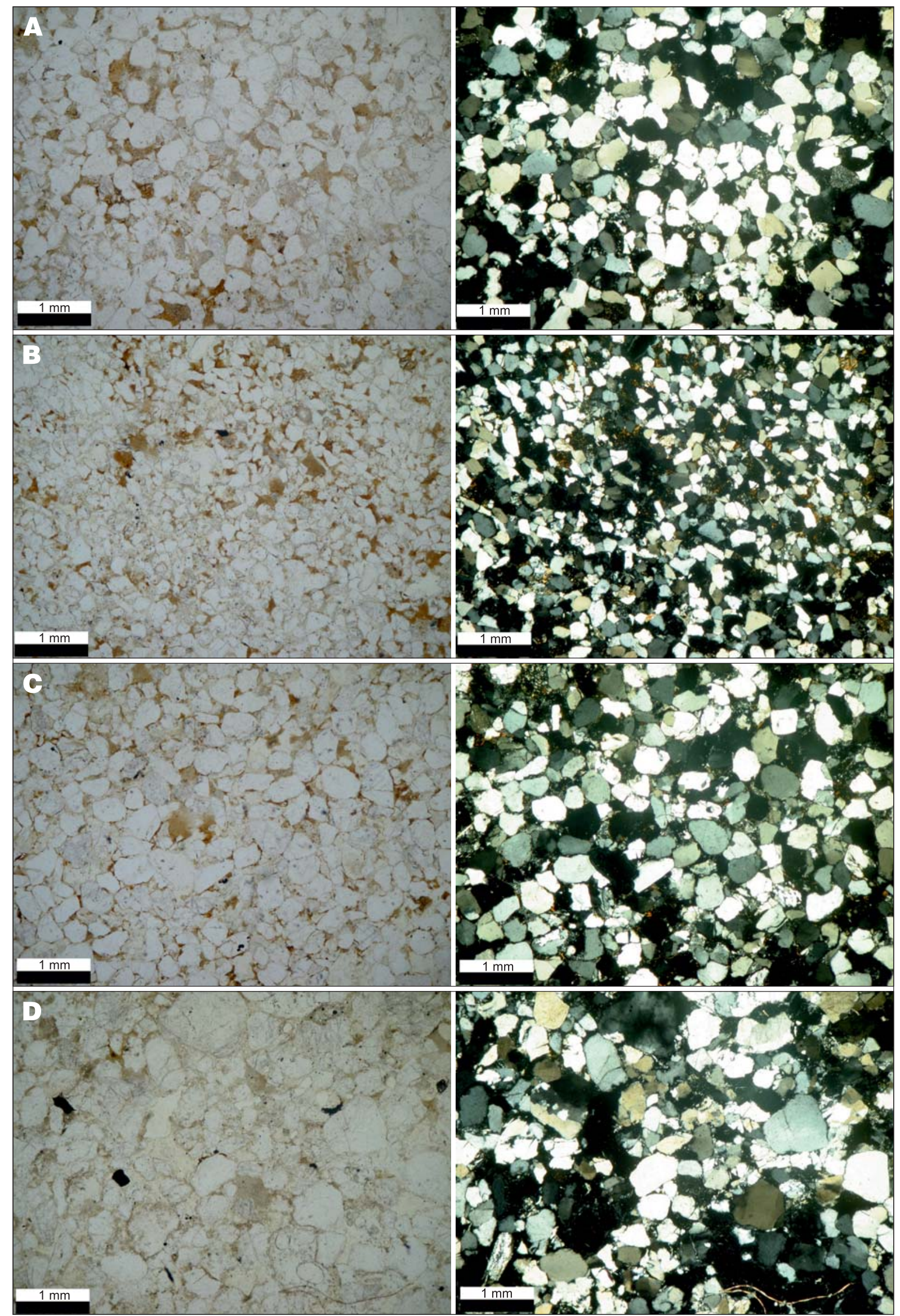

Ryc. 9. Mikroskopowe zdjęcia skał pobranych do badań (z lewej strony - jeden nikol, z prawej - nikole skrzyżowane): A mikrofotografia próbki P2; B - mikrofotografia próbki P5; C - mikrofotografia próbki P8; D - mikrofotografia próbki P12 Fig. 9. Microphotographs of the rocks samples (left - plane-polarized light, right - cross-polarized light): $\mathbf{A}$ - microphotograph of sample P2; B - microphotograph of sample P5; C - microphotograph of sample P8; D - microphotograph of sample P12 

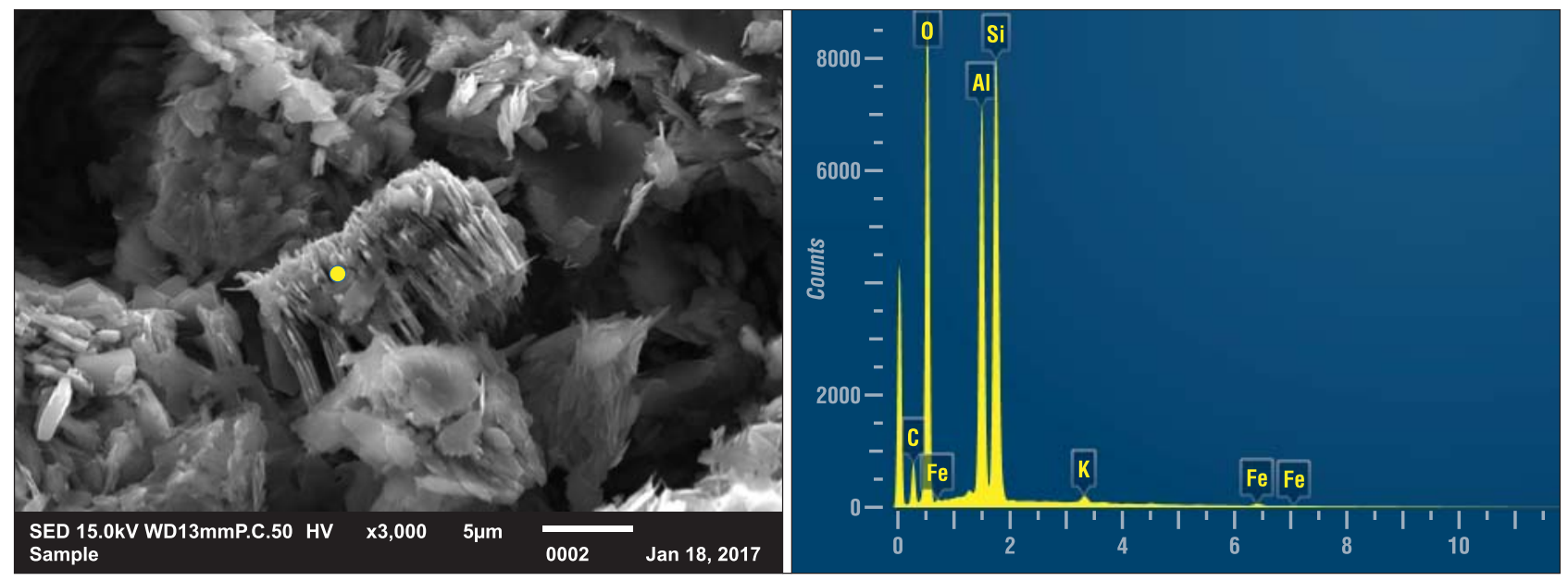

Ryc. 10. Obraz próbki P9 w elektronach wtórnych oraz widmo EDS zaznaczonego punktu

Fig. 10. SEM-SED microphotograph of sample P9 with an EDS spectrum of the selected point

są pierwotnym składnikiem spoiwa analizowanych piaskowców.

Badania katodoluminescencyjne próbek P2, P5 i P10 (tab. 1), wytypowanych do tej analizy ze względu na różnice w uziarnieniu, dowiodły, że szkielet ziarnowy badanych piaskowców jest zdominowany przez kwarc, przybierający fioletowo-brunatne barwy luminescencyjne, miejscami lekko wpadające w czerwień, lub fioletowo-niebieskie. Spoiwo w próbkach ma barwę ciemnofioletową. W obrazach katodoluminescencyjnych są wyraźnie dostrzegalne pojedyncze ziarna skaleni potasowych (o intensywnie jasnoniebieskich barwach) oraz cyrkonów. Tworzące szkielet skały ziarna kwarcu są najprawdopodobniej pochodzenia plutonicznego, o czym świadczą barwy fioletowe do niebieskich bądź brązowych z fioletowym lub niebieskim odcieniem (Götze i in., 2001). Natomiast barwy spoiwa najprawdopodobniej są związane z kaolinitem (Ehling, 1999; Szczepaniak, 2015).

\section{DYSKUSJA}

Próba określenia proweniencji piaskowców wykorzystanych do budowy portalu bazyliki św. Elżbiety Węgierskiej we Wrocławiu i przyległych do niego trzech epitafiów jest zagadnieniem istotnym między innymi ze względu na potencjalną użyteczność takich danych w celach konserwatorskich.

$\mathrm{Na}$ obszarze Polski różnowiekowe złoża jasnych (żółtoszarych) piaskowców kwarcowych o odpowiedniej bloczności i parametrach umożliwiających wykorzystanie w budownictwie występują w kilku obszarach. Wymienić tu należy kredowe piaskowce z terenu Dolnego Sląska niecki północnosudeckiej i niecki śródsudeckiej (Szczepaniak, 2015; Glapa, Sroga, 2011; Ehling, 1999; Kamieński, Kubicz, 1962), złoża jurajskich piaskowców obszaru świętokrzyskiego (Kobylec, 2008; Kamieński, Kubicz, 1962), a także kredowe piaskowce Karpat (Kobylec, 2008). Jednak $\mathrm{w}$ rozważaniach dotyczących pochodzenia piaskowców użytych do wykonania portalu i epitafiów kościoła św. Elżbiety we Wrocławiu pod uwagę wzięto jedynie złoża dolnośląskie. Takie założenie przyjęto ze względu na bliskość złóż piaskowców dolnośląskich, przekazy historyczne, że początki eksploatacji tych skał datuje się na XII w. (Szczepaniak, 2015), a także potwierdzone w literaturze informacje o wykonaniu części równowiekowych zabytków Wrocławia z tych właśnie skał (Michniewicz, 1996).
Ze względu na charakterystyke petrograficzna badane piaskowce sa podobne do piaskowców ciosowych wieku kredowego, występujących i eksploatowanych na obszarze niecki śródsudeckiej (region kłodzki) oraz północnosudeckiej (region bolesławiecki). Porównując cechy petrograficzne i parametry uziarnienia analizowanych próbek $\mathrm{z}$ danymi dostępnymi w literaturze (Ehling, 1999; Labus, 2011; Szczepaniak, 2015; Kamieński, Kubicz, 1962) można zauważyć, iż w większości wypadków zbliżone cechy mają piaskowce $\mathrm{z}$ regionu bolesławieckiego. Piaskowce kłodzkie, wieku cenomańskiego, zawierają domieszki glaukonitu, a piaskowce wieku środkowoturońskiego (np. z Radkowa) w szkielecie ziarnowym mają znaczne ilości skaleni, przez co ich skład jest zbliżony do arenitów arkozowych. Piaskowce górnoturońskie $\mathrm{z}$ tego regionu (Łężyce, Szczytna), mimo podobnego uziarnienia, charakteryzują się obecnością spoiwa krzemionkowego przy małej domieszce spoiwa ilastego, podczas gdy w analizowanych skałach mamy do czynienia ze spoiwem mieszanym, krzemionkowo-ilastym, typowym dla regionu bolesławieckiego (Labus, 2011).

Warto ponadto wspomnieć, że udokumentowana historia wydobycia piaskowców w rejonie kłodzkim (np. złoże Długopole) sięga zaledwie XVI w. (Walendowski, 2009), zatem rozpoczęła się po zakończeniu budowy gotyckiego portalu, podczas gdy wydobycie piaskowców w rejonie Lwówka Śląskiego prowadzono już w średniowieczu (Walendowski, 2010).

Piaskowce ciosowe $\mathrm{z}$ cenomanu, dolnego i środkowego turonu i środkowego koniaku niecki północnosudeckiej (Milewicz, 1961) w literaturze są często określane jako dolny, środkowy i górny piaskowiec ciosowy (Labus, 2009) albo też - ze względu na występowanie poszczególnych złóż w pobliżu konkretnych miejscowości - jako piaskowce typu Lwówek Śląski, typu Płakowice i typu Rakowice (Ehling, 1999). W składzie szkieletu ziarnowego wszystkich trzech wymienionych typów piaskowców dominuje kwarc, oprócz którego występują nieliczne ziarna skaleni i okruchy skał, a spoiwo jest krzemionkowo-ilaste. Skały te różnią się m.in. pod względem parametrów uziarnienia i cech spoiwa.

Cenomańskie piaskowce typu Lwówek oraz turońskie piaskowce typu Płakowice cechują się przeważnie grubszym uziarnieniem niż piaskowce użyte do wykonania portalu i epitafiów, a minerałem ilastym występujacym w ich spoiwie jest głównie kaolinit. Mogą ponadto zawierać skalenie i fragmenty skał (Ehling, 1999). 
Na podstawie analizy cech petrograficznych próbek piaskowców pobranych z gotyckiego portalu bazyliki św. Elżbiety we Wrocławiu, danych literaturowych oraz wyników badań kredowych piaskowców typu Lwówek Śląski, Płakowice i Rakowice, można stwierdzić, że najbardziej prawdopodobnym źródłem materiału skalnego, użytego do wykonania wymienionych elementów architektonicznych kościoła, mogą być pochodzące z niecki północnosudeckiej piaskowce koniackie typu Rakowice. Reprezentuja one górny piaskowiec ciosowy i są zlokalizowane w takich złożach jak Żerkowice, Rakowice Małe i Wartowice.

\section{WNIOSKI}

Późnogotycki portal bazyliki św. Elżbiety we Wrocławiu oraz wmurowane obok niego trzy epitafia rodziny Krappów, G.A. Scholza oraz H.S. von Wolkovitza - zostały wykonane z drobno- i średnioziarnistych piaskowców kwarcowych. Są to piaskowce o spoiwie mieszanym, krzemionkowo-ilastym, w którym oprócz kaolinitu występują także domieszki illitu. Analizowane próbki skał prawie nie zawierają skaleni i okruchów innych skał. Mają podobny skład petrograficzny, jednak wykazują niewielkie zróżnicowanie pod względem wielkości uziarnienia, zawartości spoiwa lub barwy.

Wyniki porównania $\mathrm{z}$ danymi literaturowymi oraz próbkami piaskowców z wystapień na obszarach niecek północnosudeckiej i śródsudeckiej sugerują, że materiałem skalnym użytym do budowy kościoła są piaskowce ciosowe wieku koniackiego niecki północnosudeckiej (górny piaskowiec ciosowy - typu Rakowice). Wskazują na to wielkość ziaren badanych piaskowców oraz skład mineralny szkieletu ziarnowego i spoiwa.

Badane próbki skał noszą oznaki wietrzenia i wpływu zanieczyszczeń atmosferycznych na elementy architektoniczne bazyliki św. Elżbiety we Wrocławiu, co sugeruje obecność fazy wtórnej, jaką jest gips.

Nieznaczne zróżnicowanie cech piaskowców z portalu i epitafiów może być rezultatem historycznych przebudów i zabiegów konserwatorskich, m.in. uzupełnień konserwatorskich w XIX w., o których wspomina Wandrychowska (2013a).

Zbliżony skład petrograficzny, a także podobna proweniencja materiału skalnego wskazują, że prace konserwatorskie prowadzono z zastosowaniem materiału zbliżonego do oryginalnej materii zabytkowej.

Autorzy pragną serdecznie podziękować Panu Piotrowi Wanatowi (Restoart Sp. z o.o.) za pomoc w pozyskaniu próbek z portalu oraz Dr. Pawłowi Raczyńskiemu z Instytutu Nauk Geologicznych Uniwersytetu Wrocławskiego za umożliwienie wykonania badań katodoluminescencyjnych. Prezentowane dane stanowią część pracy magisterskiej pt. Charakterystyka petrograficzna wybranych detali architektonicznych z bazyliki pw. św. Elżbiety Węgierskiej we Wrocławiu, zrealizowanej w Instytucie Nauk Geologicznych Uniwersytetu Wrocławskiego pod kierunkiem dr. Wojciecha Bartza i obronionej w $2017 \mathrm{r}$.

\section{LITERATURA}

ANTKOWIAK Z. 1991 - Kościoły Wrocławia. Muzeum Archidiecezjalne we Wrocławiu.

BARTZ W., KIERCZAK J., GASIOR M., WANAT P. 2015 - Historical materials from the post-Cisterian abbey in Kamieniec Ząbkowicki (southwestern Poland) - application of mineralogical methods for identification of source of raw materials. Arch. Anthrop. Sci., 9 (2): 279-291.

EHLING A. 1999 - Die oberkretazischien Bausandsteine Schlesiens. Dissertation, Universität Hannover.

FÖLDVÁRI M. 2011 - Handbook of thermogravimetric system of minerals and its use in geological practice. Occasional Papers of the Geological Institute of Hungary: 213.

FOLK R.1980 - Petrology of sedimentary rocks. Hemphill Publishing Company.

GLAPA W., SROGA C. 2011 - Piaskowce dolnośląskie - zagospodarowanie i eksploatacja złóż w latach 2002-2010. Zesz. Nauk. Inst. Gosp. Sur. Min. i Energ. PAN, 81: 209-226.

GÖTZE J., PLÖTZE M., HABERMANN D. 2001 - Origin, spectral characteristic and practical applications of the cathodoluminescence (CL) of quartz - a review. Mineralogy and Petrology, 71: 225-250.

KAMIENSSKI M., KUBICZ A. 1962 - Kwasoodporność piaskowców Gór Świętokrzyskich i Dolnego Śląska na tle ich własności petrograficznych. Wyd. Geol.

KLEMENTOWSKI J., MARCINÓW K. 2006 - Tempo wietrzenia piaskowcowych zabytków architektury Dolnego Śląska. Prz. Geol., 54 (12): 1044-1046.

KOBYLEC K. 2008 - Tendencje w gospodarowaniu piaskowcami budowlanymi w Polsce. Gosp. Sur. Min., 24 (4): 175-191.

KRYZA R. 2011 - Kamień w architekturze i sztuce - od Asuanu do Żagania. [W:] Żelaźniewicz A., Wojewoda J., Ciężkowski W. (red.), Mezozoik i kenozoik Dolnego Śląska. WIND, Wrocław: 195-209.

LABUS M. 2011 - Parametry przestrzeni porowej jako determinanty podatności na wietrzenie surowców skalnych dolnośląskich piaskowców ciosowych. Wyd. Pol. Śl.

LASOTA C., PIEKALSKI J. 1996 - Kościół św. Elżbiety we Wrocławiu w świetle badań archeologicznych. Wyd. UWr.

LORENC M.W., MAZUREK S. 2010 - Wybrane, nowe propozycje atrakcji geoturystycznych z Dolnego Śląska. Geoturystyka, 3-4 (22-23): 3-18.

MACIEJEWSKA B. 1997 - Elżbietańska fara. Wyd. Wratislavia.

MICHNIEWICZ J. 1996 - Niszczenie górnokredowych piaskowców ciosowych w zabytkach Wrocławia pod wpływem zanieczyszczeń atmosferycznych. Prz. Geol., 44 (3): 271-274.

MILEWICZ J. 1961 - Uwagi o piaskowcach budowlanych rejonu Bolesławca-Lwówka Śląskiego. Prz. Geol., 9 (4): 186-190.

PETTIJOHN F.J., POTTER P.E., SIEVER R. 1987 - Sand and sandstone. Springer-Verlag.

PRELL M., ZAGOŻDŻON K.D. 2011 - Kamień naturalny w wybranych obiektach komercyjnych Wrocławia. Pr. Nauk. Inst. Górn. PWr., 133 (40): 109-121.

RAMACHANDRAN V.S, PAROLI R.M., BEAUDOIN J.J., DELGADO A.H. 2002 - Handbook of thermal analysis of construction materials. Noyes Publications, William Andrew Publishing.

RODUIT N. 2007 - JMicroVision: un logiciel d'analyse d'images pétrographiques polyvalent. http://www.jmicrovision.com.

SKOCZYLAS J. 1991 - Geologia a historia kultury materialnej w Wielkopolsce. Prz. Geol., 39 (7-8): 337-339.

SKOCZYLAS J., GUNIA P. 2016 - Zastosowanie wiedzy geologicznej w archeologii. Prz. Geol., 64 (9): 734-738.

SZCZEPANIAK M. 2015 - Procesy diagenetyczne w wybranych piaskowcach Dolnego Śląska i ich znaczenie dla romańskiej architektury południowej Wielkopolski. Bogucki Wyd. Nauk.

WALENDOWSKI H. 2009 - Piaskowiec z Długopola. Minimonografie polskich kamieni budowlanych. Nowy Kamieniarz, 42 (6): 66.

WALENDOWSKI H. 2010 - Piaskowiec z Płakowic. Minimonografie polskich kamieni budowlanych. Nowy Kamieniarz, 50 (7): 110.

WANDRYCHOWSKA D. 2013a - Kościół p.w. św. Elżbiety, Wrocław. Południowy portal na elewacji wieży. Program prac konserwatorskich weryfikacja i zmiana programu po udostępnieniu obiektu z poziomu rusztowań. Arch. Dolnośl. Woj. Kons. Zabytków we Wrocławiu.

WANDRYCHOWSKA D. 2013b - Kościół p.w. św. Elżbiety, Wrocław. Epitafium rodziny Krappów. Program prac konserwatorskich - weryfikacja i zmiana programu po udostępnieniu obiektu z poziomu rusztowań. Arch. Dolnośl. Woj. Kons. Zabytków we Wrocławiu.

WANDRYCHOWSKA D. 2013c - Kościół p.w. św. Elżbiety, Wrocław. Epitafium Georga Althoffa Scholza. Program prac konserwatorskich weryfikacja i zmiana programu po udostęnnieniu obiektu z poziomu rusztowań. Arch. Dolnośl. Woj. Kons. Zabytków we Wrocławiu.

WANDRYCHOWSKA D. 2013d - Kościół p.w. św. Elżbiety, Wrocław. Epitafium Hansa Schulza von Wolkowizt. Program prac konserwatorskich - weryfikacja i zmiana programu po udostępnieniu obiektu z poziomu rusztowań. Arch. Dolnośl. Woj. Kons. Zabytków we Wrocławiu.

WANDRYCHOWSKA D. 2013e - Kościół p.w. św. Elżbiety, Wrocław. Epitafium Ehrenfrieda Fellnera i jego żony. Program prac konserwatorskich - weryfikacja i zmiana programu po udostępnieniu obiektu z poziomu rusztowań. Arch. Dolnośl. Woj. Kons. Zabytków we Wrocławiu. WYRWICKI R. 1988 - Analiza derywatograficzna skał ilastych. Wyd. UW. 